\title{
Atomic Absorption Spectrophotometric Studies on Heavy Metal Contamination in Groundwater in and around Tiruchendur, Tamilnadu, India
}

\author{
PONNUSAMY THILLAIARASU ${ }^{1 *}$, ARUMUGAM MURUGAN ${ }^{1}$ and \\ JESLIN KANAGA INBA ${ }^{2}$
}

${ }^{1}$ Department of Chemistry, Kalasalingam University, Krishnan Kovil- 626 126, Tamilnadu, India

${ }^{2}$ Department of Chemistry, Jayaraj Annapackiam CSI College of Engineering, Nazareth - 628 617, India

drpthillai@yahoo.com

Received 12 February 2013 / Revised 29 April 2013/ Accepted 7 May 2013

\begin{abstract}
In the present investigation, groundwater samples were collected from 12 places in Tiruchendur coastal area, Tamilnadu, India. Physicochemical parameters such as pH, alkalinity, electrical conductivity, hardness, total dissolved solids, dissolved oxygen, COD, BOD, sulphate, fluoride, nitrate and trace metals like chromium, zinc, copper, iron, lead, manganese and cadmium were analyzed. Standard methods were followed for the analysis of physicochemical parameters. The trace metals were analyzed in Atomic Absorption Spectrophotometer (AAS). The results were compared with WHO, ICMR, IS. The physicochemical parameters for some samples showed that the values are deviating from the set limits for the domestic purposes. The trace metal analyses are not on the exceeding side of the permissible limit in all the samples. So the trace metal values arouse no concern at present. The water quality in all the areas surveyed was found to be unfit for human consumption. Because of lack of water quality, different diseases frequently affect local people. Hence, suitable water quality management is essential to avoid contamination.
\end{abstract}

Keywords: Atomic absorption spectrophotometer, Physicochemical studies, Groundwater, Trace metals, Public Health.

\section{Introduction}

Water is the most important natural resources on our planet. It is considered absolutely essential to sustain life since the protoplasm of many living cells contains about $80 \%$ water and any substantial reduction in this level is disastrous. Groundwater is one of the prime natural resources upon which depend the survival of mankind as well as the social and economic development of the nation ${ }^{1}$. It is an important source of water supply throughout the world. It has been used for drinking for a long time and its purity has made it a wellknown source of potable water. Advancement of human civilization has put serious questions to the safe use of groundwater for drinking. 
Groundwater was once considered to be free from pollution. But the rapid industrialization made a paradigm shift to this concept. The contaminants are added to groundwater at an alarming rate. Pollutants are being added to the groundwater system through human and natural processes $^{2}$. Solid waste from industrial units is being dumped near the factories, which is subjected to reaction with percolating rain water and reaches the groundwater level.

The quality of groundwater is more important as the case of quantity. The quality varies due to a change in chemical composition of formations. The quality of water should be wholesome, safe and free from pollution of any kind. The health of the public should in no way be endangered due to epidemics associated with water borne diseases ${ }^{3}$. Absolutely pure water is never found in nature. The water found in nature contains a number of impurities in varying amounts. The present investigation was undertaken to study the groundwater quality in Tiruchendur town. Tiruchendur is one of the most important pilgrim and tourist places in Tamil Nadu. Regular monitoring of the quality of groundwater should be undertaken temporarily and spatially, to identify the sources of toxic contaminants and other inhibitory compounds that affect the potability of water. Since development, environment and public health are interlinked, it is necessary for all concerned to adopt sustainable utilization of the available water resources.

\section{Experimental}

The study area of Tiruchendur lies between latitudes $8.4902^{\circ} \mathrm{N}$ and longitudes $78.1269^{\circ} \mathrm{E}$. The study is situated in Gulf of Mannar (Bay of Bengal) and it is surrounded by Tirunelveli and Thoothukudi (India).

In the present investigation 12 groundwater samples were collected from bore wells and open wells in and around Tiruchendur are listed in Table 1. Polythene cans of 2 L capacity were made use for collection of water samples. These polythene cans were first washed with tap water, soaked in chromic acid solution for about 10-15 minutes to remove any impurities, again washed with tap water. Finally, they were rinsed with deionised distilled water. Then the polythene cans were taken for sample collection. Acids, alkalis, indicator, buffer reagents, mineral salts etc. used in the analysis were of analytical grade of high purity. Hence they were directly used without any purification.

Table 1. Groundwater sampling location in and around Tiruchendur

\begin{tabular}{cccc}
\hline S. No. & Site / Location of Sampling & S. No. & Site / Location of Sampling \\
\hline GW -1 & Nalikinar & GW -7 & Amali Nagar \\
GW -2 & Sannathi Street & GW -8 & Kurunji Nagar \\
GW -3 & Thoppur & GW -9 & Alanthalai \\
GW -4 & Jeeva Nagar & GW -10 & Kandasamypuram \\
GW -5 & Kumarapuram & GW -11 & Tiruchendur \\
GW -6 & Veerapandiapatanam & GW -12 & Ramasamypuram \\
\hline
\end{tabular}

Appropriate physical and chemical methods were applied for the determination of various parameters. So, the samples under test were subjected to physicochemical and trace metal analysis. The $\mathrm{pH}$ was measured using digital $\mathrm{pH}$ meter of Elico make model L1-120. The electrical conductivity was measured using digital conductivity meter type CM82T. Standard methods were followed for the analysis of physico-chemical parameters such as TDS, alkalinity, hardness, BOD, COD, dissolved oxygen, sulphate, fluoride, nitrate and chloride. The trace metals zinc, cadmium, copper, lead, chromium and manganese were analyzed in Atomic Absorption Spectrophotometer model GBC 932. 


\section{Results and Discussion}

The results of physicochemical analysis of different groundwater samples are presented in Table 2 and 3. Alkalinity in all the water samples lies within the range $249 \mathrm{mg} / \mathrm{L}$ to $790 \mathrm{mg} / \mathrm{L}$. The alkalinity is mainly attributable to bicarbonate ions, which is evident from absence of phenolphthalein alkalinity. All the analyzed samples are exceeding WHO permissible limit of $120 \mathrm{mg} / \mathrm{L}$. The high alkalinity values in the study area are due to the action of carbonates upon the basic materials in the soil ${ }^{4}$.

Table 2. Physicochemical characteristics of the groundwater samples

\begin{tabular}{|c|c|c|c|c|c|c|c|c|c|c|c|c|}
\hline 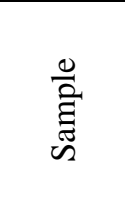 & 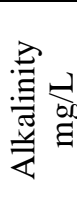 & 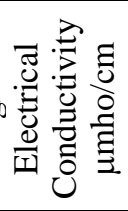 & 营兽兽 & 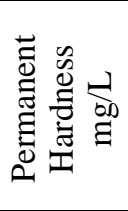 & 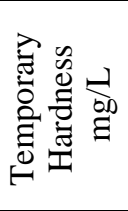 & 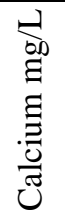 & 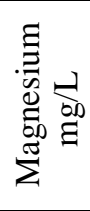 & I & 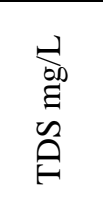 & 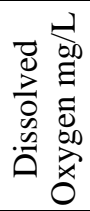 & & 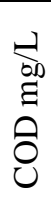 \\
\hline GW -1 & 366 & 626 & 850 & 705 & 145 & 120 & 2 & 81 & 80 & 7.6 & 2 & $T$ \\
\hline & 468 & 7 & 720 & 4 & 267 & 220 & 252 & & $>2$ & 8 & & 4 \\
\hline & 483 & 42 & 11 & 858 & 255 & 180 & 364 & 1 & $>2000$ & 8. & 1 & 3 \\
\hline & 373 & 5 & 7 & 449 & 267 & 100 & 252 & 8.09 & $>2000$ & 8.5 & 4 & 5 \\
\hline & 249 & & & & 57 & 80 & 84 & 7.55 & 520 & 7.5 & & 7 \\
\hline & 578 & 190 & & 56 & 201 & 140 & 112 & 7.50 & 1029 & 10.1 & & 5 \\
\hline & 263 & $?$ & 6 & & 17 & 180 & 196 & 7.52 & 1740 & 8. & & 4 \\
\hline & 585 & 299 & & 267 & 101 & 80 & 140 & 7.95 & 1575 & 8. & & 3 \\
\hline & 307 & 191 & 3 & 177 & 133 & 100 & 140 & 7.95 & 1250 & $9.3^{3}$ & 4 & I \\
\hline 10 & 592 & 246 & 288 & 5 & 98 & 60 & 112 & 7.61 & 1475 & 9.4 & & 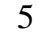 \\
\hline 11 & 570 & 827 & 1030 & 667 & 363 & 200 & 308 & 7.80 & $>2000$ & 7.9 & . & 5 \\
\hline GW 12 & 790 & 371 & 274 & 128 & 146 & 60 & 84 & 7.57 & 1773 & 8.3 & 1 & 4 \\
\hline
\end{tabular}

Table 3. Concentrations of inorganic nutrients and trace metals

\begin{tabular}{|c|c|c|c|c|c|c|c|c|c|c|c|}
\hline & $\begin{array}{c}\text { Sulphat } \\
\text { mg/L }\end{array}$ & $\begin{array}{l}\text { Lhloride } \\
\text { mg/L }\end{array}$ & $\begin{array}{l}\text { luorid } \\
\mathrm{mg} / \mathrm{L}\end{array}$ & $\begin{array}{l}\text { Nitrate } \\
\mathrm{mg} / \mathrm{L}\end{array}$ & $\begin{array}{c}\mathrm{Zn} \\
\mathrm{mg} / \mathrm{L}\end{array}$ & $\begin{array}{c}\mathrm{Cu} \\
\mathrm{mg} / \mathrm{L}\end{array}$ & $\begin{array}{c}\mathrm{Fe} \\
\mathrm{mg} / \mathrm{L}\end{array}$ & $\begin{array}{c}\mathrm{Pb} \\
\mathrm{mg} / \mathrm{L}\end{array}$ & $\begin{array}{c}\mathrm{Cr} \\
\mathrm{mg} / \mathrm{L}\end{array}$ & $\begin{array}{c}\mathrm{Mn} \\
\mathrm{mg} / \mathrm{L}\end{array}$ & $\begin{array}{c}\mathrm{Cd} \\
\mathrm{mg} / \mathrm{L}\end{array}$ \\
\hline$\overline{\mathrm{GW}}-1$ & 121 & 312 & 1 & 25 & 0.0080 & 0.017 & 0.015 & 0.021 & 1.316 & 0.011 & 0.004 \\
\hline sW - 2 & 210 & 361 & 1.1 & 30 & 0.0065 & 0.014 & 0.0001 & 0.0002 & 0.935 & 0.006 & 0.002 \\
\hline W - 3 & 262 & 288 & 0.8 & 27 & 0.0100 & 0.025 & 0.021 & 0.011 & 0.778 & 0.007 & 0.005 \\
\hline$W-4$ & 189 & 428 & 0.8 & 76 & 0.0496 & 0.023 & 0.0003 & 0.0004 & 1.121 & 0.002 & 0.006 \\
\hline GW - 5 & 244 & 391 & 0.9 & 81 & 0.0165 & 0.013 & 0.003 & 0.006 & 0.0001 & 0.003 & 0.002 \\
\hline GW - 6 & 198 & 378 & 1.1 & 45 & 0.1035 & 0.015 & 0.035 & 0.004 & 0.089 & 0.001 & 0.006 \\
\hline WW - 7 & 316 & 269 & 0.7 & 57 & 0.0102 & 0.027 & 0.009 & 0.012 & 1.083 & 0.011 & 0.003 \\
\hline W - 8 & 258 & 312 & 0.8 & 43 & 0.38 & 0.010 & 0.006 & 0.019 & 1.782 & 0.007 & 0.004 \\
\hline W- 9 & 260 & 354 & 1.4 & 65 & 0.03 & 0.007 & 0.018 & 0.059 & 1.355 & 0.009 & 0.004 \\
\hline W 10 & 193 & 398 & 0.7 & 64 & 0.28 & 0.011 & 0.045 & 0.039 & 1.150 & 0.0001 & 0.001 \\
\hline W 11 & 223 & 372 & 0.8 & 37 & 0.0 & & 0.005 & 0.016 & 1.954 & 0.008 & 0.002 \\
\hline SW 12 & 248 & 442 & 0.8 & 25 & 0.0178 & 0.014 & 0.027 & 0.025 & 0.879 & 0.007 & 0.003 \\
\hline
\end{tabular}

It was observed that the conductivity values of the water samples constitute the range 99 to $925 \mu \mathrm{mho} / \mathrm{cm}$. In most of the samples the electrical conductivity exceeded the domestic water standards of $300 \mu \mathrm{mho} / \mathrm{cm}$. These high values of electrical conductivity are due to the high concentrations of ionic constituents present in the water bodies under study and reflect the contributions from salinity intrusion as well as pollution by domestic wastes ${ }^{5}$.

The prominent hardness causing ions are calcium and magnesium. In the study area, total hardness varies from 160-1113 mg/L. The desirable limit according to IS standard is $300 \mathrm{mg} / \mathrm{L}$. 
The water samples of the study area may be termed as hard except the samples GW-5, GW-9, GW-10 and GW-12. Although hardness has no adverse effect on health, there is evidence that hard water plays a role in heart disease ${ }^{6}$. While bathing with hard water, the residues of hardness, that is soap precipitate may remain in the pores of skin causing roughness and discomfort $^{8}$. Calcium concentration varies from 60 to $220 \mathrm{mg} / \mathrm{L}$. WHO permissible limit is $100 \mathrm{mg} / \mathrm{L}$. Most of the samples exceed the permissible limit. Magnesium concentration was observed in the samples range from 84 to $364 \mathrm{mg} / \mathrm{L}$. WHO standard is $50 \mathrm{mg} / \mathrm{L}$. In all the samples magnesium exceeds the permissible limit. Magnesium rich water may cause the gastrointestinal irritation in the presence of sulphate and act as laxative to human beings ${ }^{7}$.

In the present study, $\mathrm{pH}$ value ranges from 7.37 to 8.09 . The limit of $\mathrm{pH}$ value for drinking water is 6.5 to 8.5 (ICMR, 1975). This clearly indicates that all the samples were found to be alkaline.

Total dissolved solids (TDS) in the study area varied from 520 to above $2000 \mathrm{mg} / \mathrm{L}$ water containing more than $500 \mathrm{mg} / \mathrm{L}$ of TDS is not desirable for drinking water purpose. The observed TDS values are higher than the maximum permissible limit value of TDS is found in most of the study area. So people of these areas have laxative and sometimes the reverse effect due to the high solid content ${ }^{8}$.

Dissolved oxygen (DO) is one of the important pollution parameters, which measures the extent of organic as well as biological pollution load to a water body. The DO content of water is an index of its sanitary condition ${ }^{9}$. The recommended DO limit for all the domestic purposes is 4-6 ppm. The observed values for all the samples are slightly above the limit set by WHO and these high values may be probably due to the recharge of the groundwater by the surface water.

The BOD and COD parameters pointing out the measure of oxidative decomposable organic components in water, are another two parameters stating the level of pollution like DO. BOD value ranges from 1 to $4 \mathrm{mg} / \mathrm{L}$ and COD value ranges from 3 to $7 \mathrm{mg} / \mathrm{L}$. All COD level is below the WHO permissible level of $10 \mathrm{mg} / \mathrm{L}$ for domestic water whereas in few samples GW-4, GW-5 and GW-9 BOD exceeds the IS limit of $3 \mathrm{mg} / \mathrm{L}$. This finding indicates contribution of biodegradable pollutants, presumably from sanitary waste in pilgrimage area ${ }^{8}$.

Sulphate concentration in the study area varies from 121 to $316 \mathrm{mg} / \mathrm{L}$. WHO permissible limit is $200 \mathrm{mg} / \mathrm{L}$. A few samples (GW - 3, 5, 7, 8, 9, 11, 12) exceed the permissible limit. Excess sulphate content induces diahorrea and cathartic effect on human health ${ }^{7}$.

Chloride imparts salty taste to water, depending on the presence of cation constituents. In the present investigation chloride content varies from 269 to $442 \mathrm{mg} / \mathrm{L}$. WHO permissible limit is $200 \mathrm{mg} / \mathrm{L}$. In all the samples, chloride concentration exceeded the WHO permissible limit. Adverse health effects on humans have been reported from intake of waters containing even higher content of chloride.

Fluoride is important in human nutrition for the normal development of bones. It should not exceed $1.5 \mathrm{mg} / \mathrm{L}$. The fluoride content is less than $1 \mathrm{mg} / \mathrm{L}$ in most of the samples except GW-2, GW-6 and GW-9. Use of phosphate fertilizers may also contribute to high fluoride content in groundwater. These chemical pollutants affect man's health not only directly but also indirectly by accumulating aquatic life (e.g. fish) used as human food ${ }^{10}$.

Nitrate is effective plant nutrient and moderately toxic. Nitrate content in the study area varies from 25 to $81 \mathrm{mg} / \mathrm{L}$. WHO permissible limit is $45 \mathrm{mg} / \mathrm{L}$. A few samples GW-4, GW5, GW-7, GW-9 and GW-10 exceed the nitrate in drinking water has also be found to cause methemoglobinaemia (blue babies syndrome) in infants. Repeated heavy doses of nitrates on ingestion may cause carcinogenic diseases ${ }^{11}$. 
Zinc is an essential element for both animals and man. It is necessary for the functioning of various enzyme systems, deficiency of which leads to growth retardation. Low intake of Zinc results in retardation of growth, immaturity and anemia condition known as zinc deficiency syndrome ${ }^{12}$. The concentration of zinc in the study area ranges from 0.0065 to $0.3850 \mathrm{mg} / \mathrm{L}$. Since the recommendations for the domestic water supplies are $5 \mathrm{mg} / \mathrm{L}$ the levels of zinc in the groundwater are safe enough for drinking and other domestic purposes.

Copper is an essential element for human body. But excessive large doses may lead to mucosal irritation and corrosion, hepatic and renal damage and central nervous system. The copper concentration in the groundwater samples varies from 0.007 to $0.027 \mathrm{mg} / \mathrm{L}$. All the values are well within the WHO permissible limit of $1 \mathrm{mg} / \mathrm{L}$. The groundwater of these areas can be safely used as a source of drinking water supplies.

The maximum permissible limit of iron content in drinking water is set as $0.3 \mathrm{mg} / \mathrm{L}$ (IS 1991). The concentration of iron in groundwater of the study area ranges from 0.0001 to $0.045 \mathrm{mg} / \mathrm{L}$. Studies on the iron content of the groundwater in Tiruchendur have shown that all the values are within the permissible limit.

Lead poisoning has been recognized as an occupational illness for centuries and it is linked with both severe and subtle health damages. Higher concentration of lead in drinking water has adverse effect on central nervous system, blood cell and may cause brain damage. The permissible limit for lead in drinking water is $0.05 \mathrm{mg} / \mathrm{L}$. The lead content in the study area ranged from 0.0002 to $0.059 \mathrm{mg} / \mathrm{L}$ (Table 4 and 5). The groundwater of the study area can be safely used as a source of drinking water supplies (Figure 1).

Table 4. Estimation of $\mathrm{Pb}$ by AAS Studies-Preparation of Calibration curve with Standard Lead Solution (Element : Pb (lead) Calibration mode: Concentration)

\begin{tabular}{ccccccc}
\hline $\begin{array}{c}\text { Sample } \\
\text { Label }\end{array}$ & $\begin{array}{c}\text { Conc. } \\
\mu \mathrm{g} / \mathrm{mL}\end{array}$ & \%RSD & $\begin{array}{c}\text { Mean } \\
\text { Abs. }\end{array}$ & & Replicates \\
\hline Cal Blank & - & High & 0.0012 & 0.0001 & 0.0021 & 0.0015 \\
Standard 1 & 2.51 & 1.48 & 0.1605 & 0.1591 & 0.1632 & 0.1591 \\
Standard 2 & 5.02 & 0.12 & 0.3242 & 0.3239 & 0.3246 & 0.324 \\
Standard 3 & 10.04 & 0.48 & 0.6483 & 0.6514 & 0.6451 & 0.6484 \\
Standard 4 & 15.056 & 0.33 & 0.9575 & 0.9601 & 0.9585 & 0.954 \\
\hline
\end{tabular}

Note: Standard 1, 2, 3 and 4 are different concentrations of lead solution for preparation of calibration curve

Table 5. Estimation of $\mathrm{Pb}$ from groundwater sample station by AAS studies

\begin{tabular}{ccccccc}
\hline $\begin{array}{c}\text { Sample } \\
\text { Label }\end{array}$ & $\begin{array}{c}\text { Conc. } \\
\mu \mathrm{g} / \mathrm{mL}\end{array}$ & \%RSD & $\begin{array}{c}\text { Mean } \\
\text { Abs. }\end{array}$ & \multicolumn{3}{c}{ Replicates } \\
\hline Sample blank & - & High & 0.0015 & 0.0051 & 0.0012 & -0.0017 \\
GW1 & 0.021 & High & 0.0013 & 0.0023 & 0.0004 & 0.0013 \\
GW2 & 0.037 & High & 0.0024 & 0.0031 & 0.0039 & 0.0003 \\
GW3 & 0.011 & High & 0.0007 & 0.0016 & 0.0011 & -0.0005 \\
GW4 & ND & High & -0.0056 & -0.0095 & -0.0046 & -0.0027 \\
GW5 & 0.016 & High & 0.001 & 0.0011 & 0.0006 & 0.0014 \\
GW6 & 0.004 & High & 0.0002 & 0.0023 & 0.0006 & -0.0023 \\
GW7 & 0.012 & High & 0.0008 & -0.0025 & 0.0031 & 0.0016 \\
GW8 & 0.019 & High & 0.0012 & 0.0013 & 0.0026 & -0.0003 \\
GW9 & 0.059 & High & 0.0038 & 0.0009 & 0.0049 & 0.0055 \\
GW10 & 0.039 & High & 0.0025 & 0.0045 & 0.0023 & 0.0007 \\
GW11 & 0.016 & High & 0.0011 & 0.0046 & -0.0024 & 0.0011 \\
GW12 & 0.014 & HIGH & 0.0010 & 0.0044 & 0.0042 & 0.0010 \\
\hline
\end{tabular}




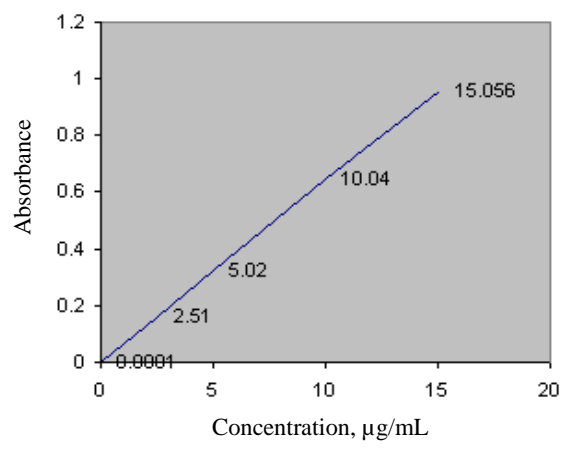

Figure 1. Estimation of lead by AAS studies

Chromium is an essential nutrient for plant and animal metabolism. The $0.05 \mathrm{mg} / \mathrm{L}$ is the permissible limit of chromium in drinking water as recommended by WHO. The chromium content in the study area ranged from 0.0001 to $1.954 \mathrm{mg} / \mathrm{L}$. It was found that all samples are above permissible limit. Excess of chromium present in human body causes bronchial cancer in humans.

Manganese content in the study area ranged from 0.0001 to $0.011 \mathrm{mg} / \mathrm{L}$. The permissible limit of manganese is $0.1 \mathrm{mg} / \mathrm{L}$. All the samples in the study area are well within the permissible limit. Water in these areas is safe for domestic purpose.

Concentration of cadmium in the study area ranged from 0.001 to $0.006 \mathrm{mg} / \mathrm{L}$. The permissible limit of cadmium in drinking water is $0.01 \mathrm{mg} / \mathrm{L}$. The levels of cadmium in public water supplies are normally very low. Therefore, the groundwater of the study area does not present any cadmium hazards to humans.

\section{Conclusion}

In general, the water quality in all the areas surveyed was found to be unfit for human consumption for one reason or another. Hence, it is recommended that suitable water quality management is essential to avoid any further contamination. From the generated data and the foregoing discussion, it can be concluded that most of the groundwater samples in Tiruchendur area are not suitable for drinking use. Hence the groundwater samples require treatment before being used.

\section{References}

1. Birdie G S and Birdie J S, Water Supply and sanitary Engineering, Dhanpat Rai Publishing Company, New Delhi, 2002.

2. Sharma B.K and Kaur H, Environmental Chemistry, $3^{\text {rd }}$ Ed., Goel Publishing House, Meerut, 1996-1997.

3. Duggal K.N, Elements of Environmental Engineering, S Chand and Company Ltd., New Delhi, 2002.

4. Ahmed M J, Haque M R, Ahsan A, Siraj S, Bhuiyan M H R, Bhattacharjee S C and Islam S, Pak J Anal Environ Chem., 2010, 11(2), 1-11.

5. Thillai Arasu P, Hema S and Neelakantan M.A, Indian J Sci \& Technol., 2007, 1(2), 1-7.

6. Basavaraja Simpi, Hiremath S M, Murthy K N S, Chandrashekarappa K N, Patel A N and Puttiah E T, Global Journal of Science Frontier Research, 2011, 11(3), 31-34.

7. Sirajudeen K, Thillai Arasu P, Puthiya Sekar C, Neelakantan M A and Poongothai S, Int J Chem Sci., 2009, 7(2), 1421- 1426. 
8. Jeyakumar T, Indira S and Thillai Arasu P, Indian J Environ Protect., 2003, 23, 256-260.

9. Varunprasath K and Daniel N A, Iranica J Energy \& Environ., 2010, 1(4), 321 - 325.

10. Park K, Park's Text Book of Preventive and Social Medicine, $17^{\text {th }}$ Edition Banarsidas Bhanot Publisheres, Jabalpur, India, 1997.

11. Muniyan M and Ambedkar G, Int J Environ Biology, 2011, 1(2), 15-18.

12. Muthulakshmi L, Ramu A and Kannan N, EJEAFChe., 2012, 11(2), 32 - 37. 